\section{International Scientific Journal Theoretical \& Applied Science}

p-ISSN: 2308-4944 (print) e-ISSN: 2409-0085 (online)

Year: $2015 \quad$ Issue: 03 Volume: 23

Published: $30.03 .2015 \quad$ http://T-Science.org

SECTION 32. Jurisprudence.
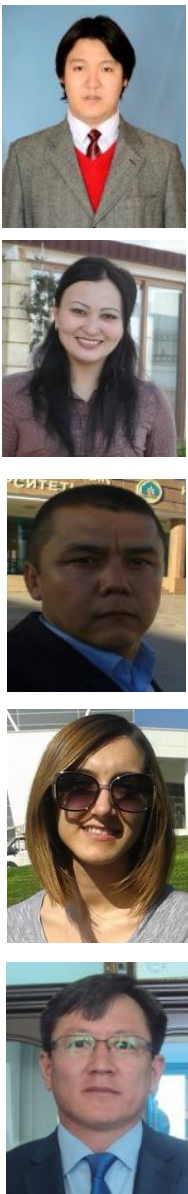

Yernar Sailaubekovich Shalkharov Doctor of law (PhD), Bachelor of biology

Department of Strategic Planning of

Scientific-Research Developments International Kazakh-Turkish University by name of Yassavi, Kazakhstan yernar_shalkharov@bk.ru

Manshuk Mazhitovna Imanbekova Doctor of law (PhD),

Department of Strategic Planning of Scientific-Research Developments International Kazakh-Turkish University by name of Yassavi, Kazakhstan

Daulet Kozhambek

Doctor of law (PhD),

Department of Strategic Planning of Scientific-Research Developments International Kazakh-Turkish University by name of Yassavi, Kazakhstan

Chamli Tilbe

Doctor of biology (PhD), Department of molecular exobotanic Biology Faculty,

Dzhelal Boyar Universit, Manisa

Nurlan Muhtarovich Batyrbaev Candidate of law Science (PhD),

Department of Strategic Planning of Scientific-Research Developments International Kazakh-Turkish University by name of Yassavi, Kazakhstan

\title{
ECOLOGICAL NECESSITY IN SOUTH KAZAKHSTAN IN CREATING PRIVATE SCIENTIFIC ORGANIZATIONS CARRYING ON PERSPECTIVE PLANNING OF FORCIFICATION OF FOREST GANE POOL BY MEANS OF DEVELOPMENT AND APPLICATION OF ARACHIDONIC ACIDS WITH FUNGICIVE PROPERTIES AS AN INDUCTOR OF PLANT IMMUNITY
}

\footnotetext{
Abstract: In this article there were presented current ecological situation in the South Kazakhstan area including air pollution effect from transport, whole air pollution effect from sun radiation and influence of neighbor regions as Aral area. As a solution authors presented innovational way to create new kind of private organization working with specialized uni-disciplinary methodology to find out landing of coniferous plants to increase the rate of finances in atmosphere as an anti effect to air pollution. It is actually possible only with special rights to such organization and behaves to authority of legal mechanisms.

Key words: plant immunity, inductor of grow, forest gene pool, fortification band, fungitive properties, perspective planning.

Language: English

Citation: Shalkharov YS, Imanbekova MM, Kozhambek D, Tilbe C, Batyrbaev NM (2015) ECOLOGICAL NECESSITY IN SOUTH KAZAKHSTAN IN CREATING PRIVATE SCIENTIFIC ORGANIZATIONS CARRYING ON PERSPECTIVE PLANNING OF FORCIFICATION OF FOREST GANE POOL BY MEANS OF DEVELOPMENT AND APPLICATION OF ARACHIDONIC ACIDS WITH FUNGICIVE PROPERTIES AS AN INDUCTOR OF PLANT IMMUNITY. ISJ Theoretical \& Applied Science 03 (23): 146-152.

Soi: http://s-o-i.org/1.1/TAS*03(23)25 Doi: crossef http://dx.doi.org/10.15863/TAS.2015.03.23.25
} 
The South-Kazakhstan region especially Turkestan is located on the south of Kazakhstan, within the limits of east part of Turan lowland and western off spurs of Tien Shan. The greatest part of territory is flat, with unevenly-ridge sands Kyzylkum, by desert of Shardara (on a south-west, on leftbankness of Syrdarya) and Moyinkum (in the north, on left-bankness of Chu river). North part is busy at the desert Betbak Dala, on an extreme south is Hungry desert (Mirzashol). Middle part of area is occupied by the backbone of Karatau mountains, on a southeast are western outskirts of Talas Alatau, backbones of Karzhantau and Ugam area. Thus, it is possible bravely to suppose that plenty of the deserted earth negatively affects to pedosphere of territory, that confirms a subzero output-input of totality of processes of absorption, converting and use of energy of quanta of light into endeorganical reactions ratio once again. Otherwise speaking, it is problematic to syntheses crisp air from carbon dioxide which is extremely necessity to population inhabited in that region.

To the real moment this question was examined from the different points of view, beginning from state nature protection examinations, ending the professional commissions of the UNO. The question was examined by environmentalists mostly on atmospheric, radiological and influence levels as in part of influence of aral sea calamity on the Turkestan region. However scientists were not examine other factor - geological factor. Particularly, this omission happened from after to insufficiency in the region of legal entities, researches of derivats, included in the competence of that [1] and biocenosis [2] on one certain region of South-Kazakhstan Area - probably in the Turkestan region.

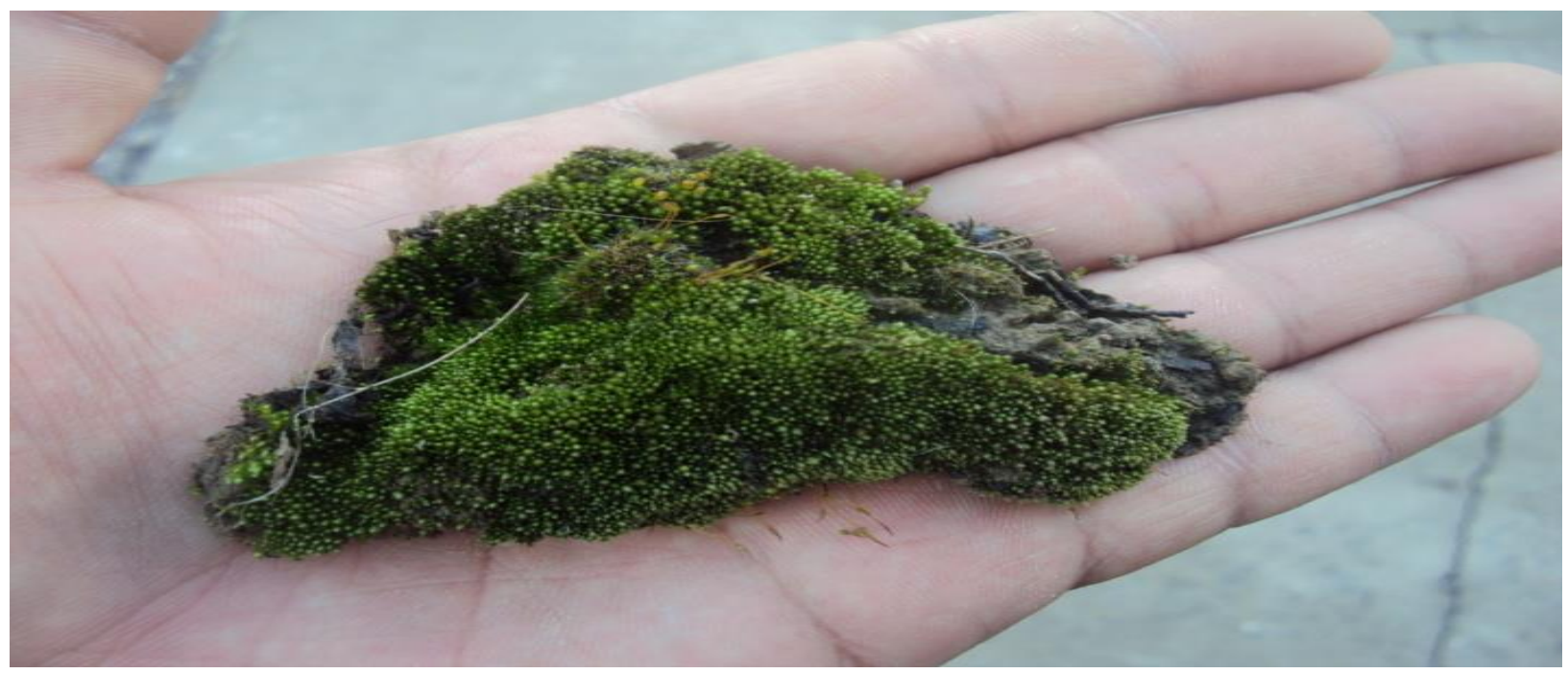

Picture 1 - Researched moss example.

So, creation of such research organization would assist fixing the price of the forest [3] and taking of inventory of forest fund [4] coming from present forest genetic reservats. This judgment I consider just, because during the unauthorized field works on territories of village of Kumtuun researchers group found out the rare standards of moss of plant from Anthocerotes family class, that characterizes soil as suitable for the height of conifers of family of Pínus sylvéstris. This statement considers as reasonable because morphology of Anthocerotes supposes by itself symbiosis with Pínus sylvéstris. In proof to everything the Turkestan region already abounds by itself by a presence on this locality of population of Thúof ja family cypress. So returning back to the legislation of Republic of Kazakhstan it is necessary foremost to mark concerning forestry, that the aim of forest increasing rate is creation of planting on the territories before not occupied by the forest [5].

\section{Legal difference between private and public planting out forest legislatively.}

\begin{tabular}{|l|l|c|}
\hline & $\begin{array}{c}\text { STATE FOREST PLANTING SECTOR } \\
\text { Article 88 Forest Code of Kazakhstan }\end{array}$ & $\begin{array}{c}\text { PRIVATE FOREST PLANTING SECTOR } \\
\text { Article 27 Forest Code of Kazakhstan }\end{array}$ \\
\hline $\mathbf{1}$ & purveyance of wood & to conduct forestry and forest using on areas of private \\
\hline
\end{tabular}

ISPC The Best of European Innovations, Gothenburg, Sweden 


\begin{tabular}{|c|c|c|}
\hline & & $\begin{array}{l}\text { forest fund, being in their property or long-term land- } \\
\text { tenure, ecologically by the acceptable methods and } \\
\text { methods, envisaged by the real Code and other legislative } \\
\text { acts of Republic of Kazakhstan. }\end{array}$ \\
\hline 2 & purveyance of soft resin, arboreal juices; & $\begin{array}{l}\text { to provide a guard, defence, improvement of the sanitary } \\
\text { state of the forests being in their property, and care of } \\
\text { them; }\end{array}$ \\
\hline 3 & $\begin{array}{l}\text { purveyance of second-rate arboreal resources } \\
\text { (bark, branches, stumps, roots, leaves, buds); }\end{array}$ & $\begin{array}{l}\text { to give to the authorized organ materials, necessary for } \\
\text { conduct of state account of forest fund, state forest } \\
\text { cadastre, in order to set by the Kazakhstan Republic } \\
\text { legislation. }\end{array}$ \\
\hline 4 & $\begin{array}{l}\text { side forest uses (pasturing of cattle, deer, } \\
\text { breeding of animals for fur, placing of beehives } \\
\text { and apiaries, truck farming, water-melon and } \\
\text { growing of another agricultural cultures, } \\
\text { purveyance and collection of medical plants and } \\
\text { technical raw material, garden-stuffs, nuts, } \\
\text { mushrooms, berries and other food products, } \\
\text { moss, forest bedding and abscissed leaves, } \\
\text { reed); }\end{array}$ & $\begin{array}{l}\text { to provide fire-prevention and sanitary arrangement of } \\
\text { areas of private forest fund, being in their property or } \\
\text { long-term land-tenure, accept necessary measures on } \\
\text { extinguishing of forest fires, fight against wreckers and } \\
\text { illnesses of the forest }\end{array}$ \\
\hline 5 & $\begin{array}{l}\text { use areas of state forest fund for the needs of } \\
\text { the hunting growing; }\end{array}$ & $\begin{array}{l}\text { to conduct registration of forest fires on the areas of } \\
\text { private forest fund, being in their property, and } \\
\text { consequences from them in the order certain the } \\
\text { Kazakhstan Republic Legislation. }\end{array}$ \\
\hline 6 & use areas of state forest fund for research aims; & \\
\hline 7 & $\begin{array}{l}\text { use areas of state forest fund for health, } \\
\text { recreational, historical, cultural, tourist and } \\
\text { sport aims; }\end{array}$ & \\
\hline 8 & $\begin{array}{l}\text { use areas of state forest fund for growing of } \\
\text { planting-stock of arboreal and shrub breeds and } \\
\text { plantation planting of the special setting. }\end{array}$ & \\
\hline
\end{tabular}

However, analyzing the situation from the pragmatic point of view the state does not give such opportunity to private organizations of assistance in this aspect an adequate for the performance of the objective pre-arranged by them [7-p.5]. As is generally known from a foregoing code state support of private foresting comes true that no more regulated terms, where plantation growing of fast-growing arboreal and shrub breeds in industrial and power aims - ten-fifteen years, and creation and development of private Sylvia - five-ten years [8-p.14]. These terms are not adequate for organizations whose competences has indicated and included in the article 75 introduction of forest flora and fauna, where renewal and reproduction of kinds and forms of plants and animals in forest biocenoses are produced by the way of reinduction of the best representatives of local aboriginal flora and fauna [9-p.2].

So that to educe more better standards it is necessary elementaryly to compare at least five generations according to G.J.Malkins. Greater term fifteen years [10-p.4]. Even taking to account that an adult plant forms fully its morphology to five years only three generations leave on an analysis, what not enough, to bring in what or change in genetics of plant [11-p.6]. The terms indicated in a code were formed partly more not possession the legislative bodies of elementary information by virtue of factor is concerning the inhibitors of height in naked seed plants, because exactly it is a point from that it is necessary to push off for gaining end to analyze genetics of plant, in order to synthesize a necessary inductor that would allow to give complete reliable information already to two years of life of plant instead of five [12-p.13].

However and it does not give to decide on standard fifteen years, because in the process of artificial evolution of cages of plant there can be force-majeure circumstances at that hydrixicorical acids can lead itself differently at co-operating with a natural vegetable environment [13-p.1]. However without the proper researches it is difficult to educe a reliable prediction [14-p.20]. Probably these researches the authorized public organs engage in, however it is difficult to suppose by virtue of incompetence and неостепененности of skilled resources, that results will appear very soon [15-p.5]. Commercial establishments would do the proper 
breach at presence of грантовского potential of country far quicker explained here in creation of product that Kazakhstan would export in other countries [16-p.9].

Thus, for the improvement of ecological situation in an atmosphere conifers would play the key role in clearing out an atmosphere on territory of South-Kazakhstan Area, not only by virtue of process of photosynthesis but also from after phitancites of the coniferous plants contained in a best, that beneficially enough influences on the features of organism and immunity of homo sapiens [17-p.17]. Similarly it is unless important to mark the degrees of muddiness of three key factors on territory of the South-Kazakhstan area [18-p.11]. Thus, statistically it is possible to look after the next indexes, where the degree of contamination of air environment from a motor transport makes $19 \%$, the degree of contamination of water pool makes $7 \%$, contamination of atmospheric air (water pool) makes $72 \%$ and $2 \%$ other factors [19p.8].

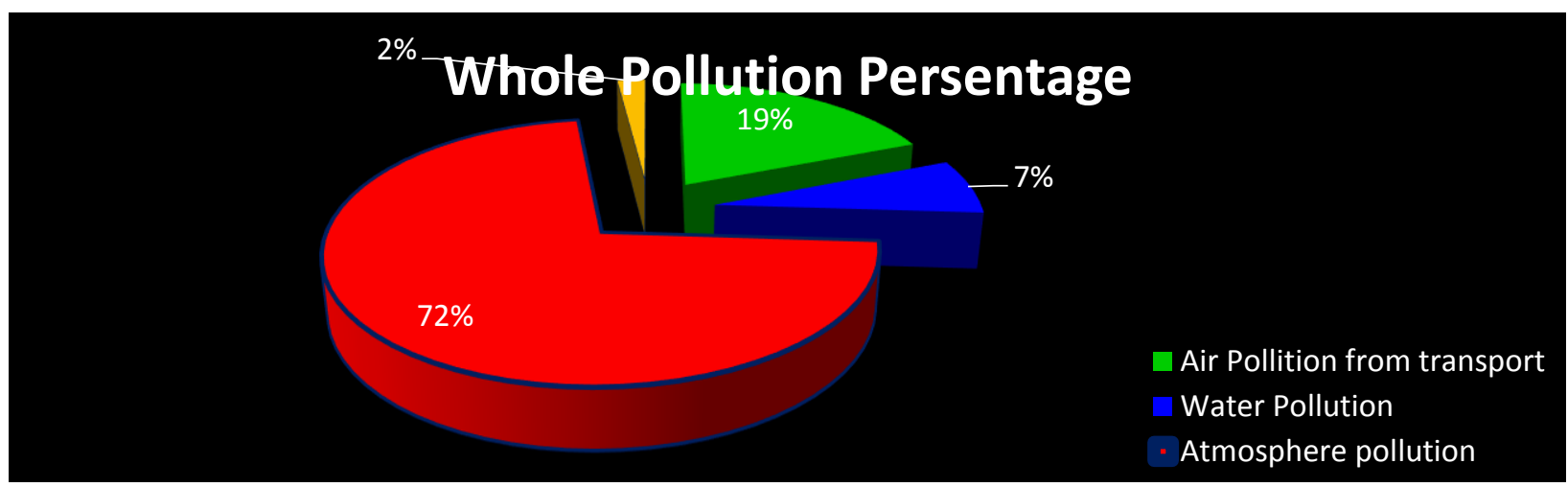

Pie chart 1 - Percentage of pollution.

But parallel to pollution there exist theory of anti pollution [20-p.17]. It means that even with influencing external factor, region have enough strench to oppose the pollution [21-p.3]. After it is possible to analyze whole percentages in anological regions where the highest rates of anti-pollution percentage dominate in Almaty Region [22-p.5]. As a second group of sharply increased anti-pollution region we can consider Ust-Kamenogorsk and the lawest anti-pollution region is Ural. Espessially it proves quantity of fitancites in region [23-p.11].

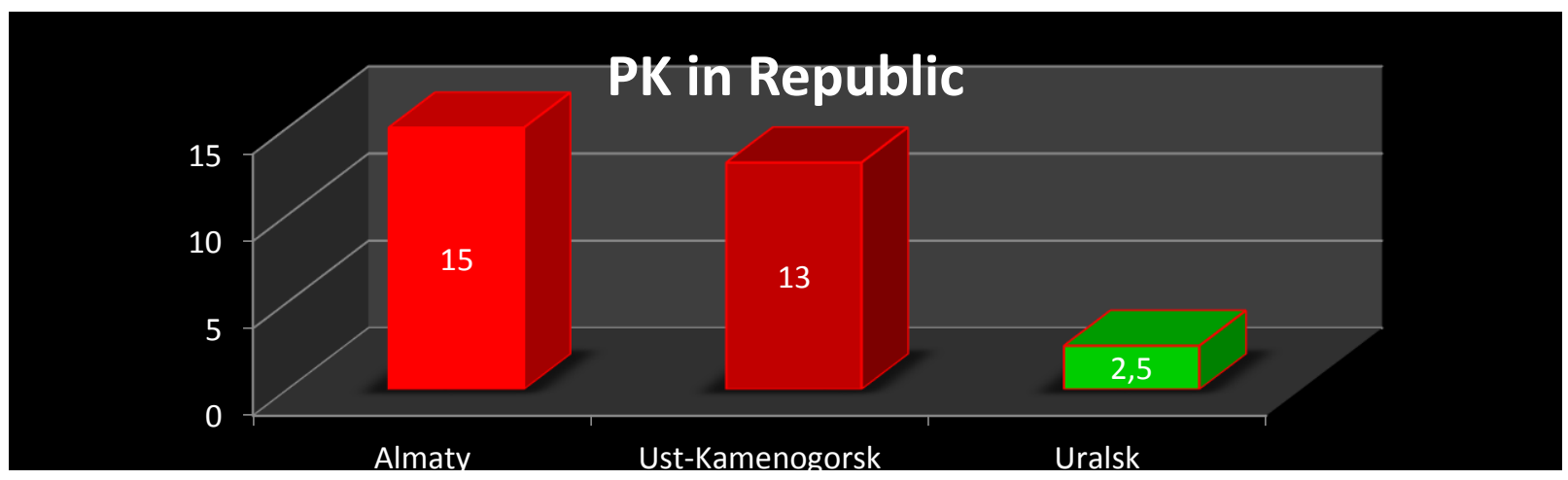

Diagram 1 - Range of pollution in three key cities with more polluted atmosphere.

Thus there's been a lot of scientific evidence where even radiology as Chernoble was cleaned up in air pollution with fitancitus from ponos silvvesttrus [24-p.1]. Thus the effect to health from fitancites espessially after pollution is enormous [25-p.90] 


\section{BACKGROUND.}

It will be right to point out firstly lots of thanks to command and partners consisting of Imanbekova Manshuk as coordinator in sphere of perspective planning, Kozhambek Daulet as legal Representative of project in public relation sector, Nurlan
Muhtarovich Batyrbaev as Domestic Expert in legislative mechanisms, Nurzhan Kenesovich Kulekeev as commissar of ecomomic sequirity and Shamuhammet Akmadov as assistant.

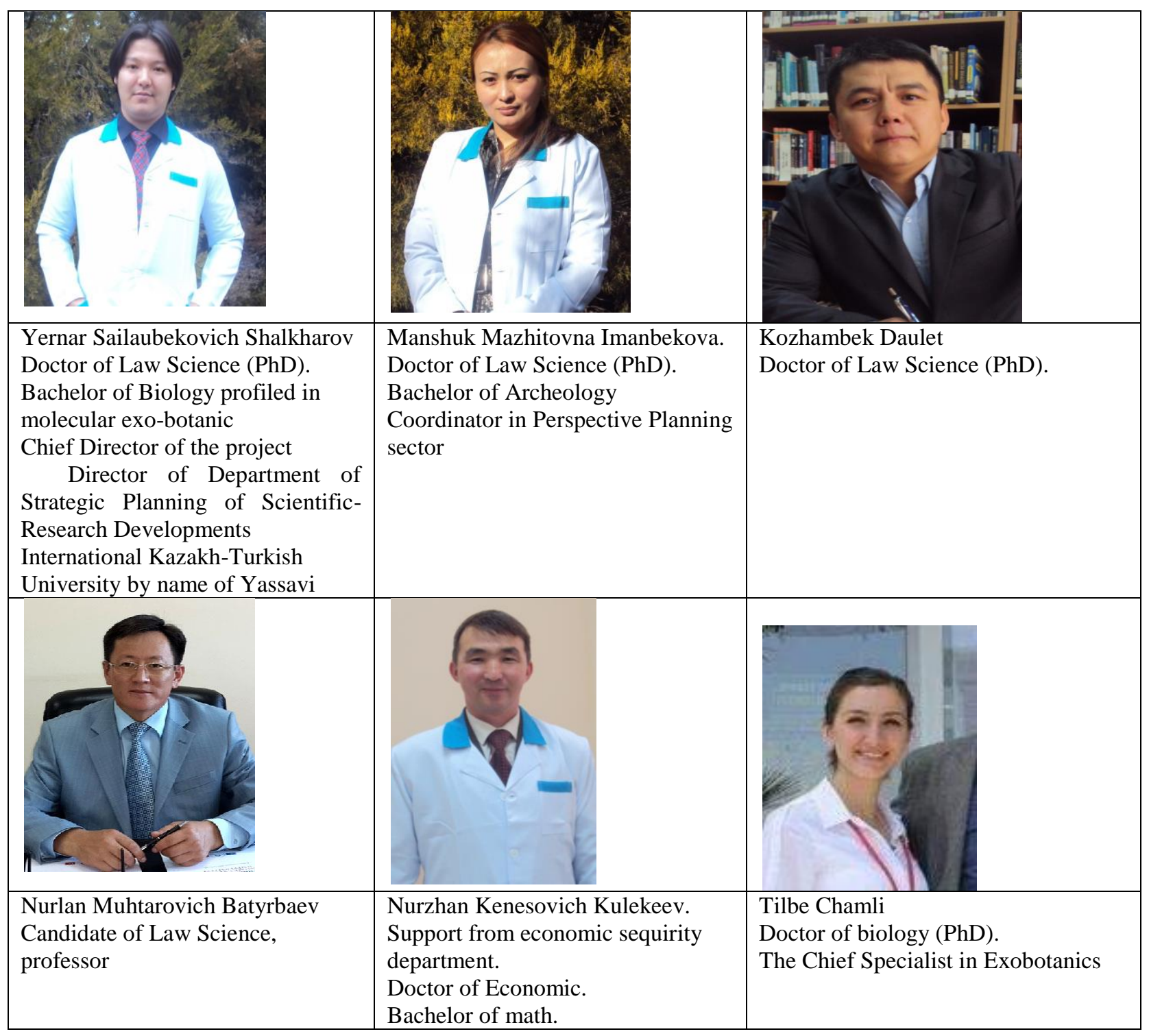

\section{References:}

1. (2011) Forest Code of Kazakhstan Republic №452-IV from 05.07.11 Legal act statement 18 of article 4.

2. (2011) Forest Code of Kazakhstan Republic №452-IV from 05.07.11 Legal act statement 15 of article 4 .
3. (2011) Forest Code of Kazakhstan Republic №452-IV from 05.07.11 Legal act statement 68 of article 4.

4. (2011) Forest Code of Kazakhstan Republic №452-IV from 05.07.11 Legal act statement 43 of article 4 . 
5. (2011) Forest Code of Kazakhstan Republic №452-IV from 05.07.11 Legal act statement 2 of article 71 .

6. (2011) Forest Code of Kazakhstan Republic №452-IV from 05.07.11 Legal act statement 4 of article 6.

7. Abdybekova AM, Torgerson PR (2012) Abstract, Frequency distributions of helminths of wolves in Kazakhstan, Veterinary Parasitology, Volume 184, Issues 2-4, 23 March 2012, pp. 348-351.

8. Vera N. Pavlova, Svetlana E. Varcheva, Raushan Bokusheva, Pierluigi Calanca (2014) Original Research Article, Modelling the effects of climate variability on spring wheat productivity in the steppe zone of Russia and Kazakhstan Ecological Modelling, Volume 277, 10 April 2014, pp. 57-67.

9. E. Kozhakhmetova, A. Zagidullina, T. Appazova (2015) Original Research Article Assessing the accuracy of the climate data of the grid database (CRU TS 2.1) in the territory of Kazakhstan Quaternary International, In Press, Corrected Proof, Available online 20, January 2015

10. A. Sultanov, A. Abdybekova, A. Abdibaeva, Z. Shapiyeva, T. Yeshmuratov, P.R. Torgerson (2014) Original Research Article, Epidemiology of fishborne trematodiasis in Kazakhstan Acta Tropica, Volume 138, October 2014, pp. 60-66,

11. Xuanhua Chen, Zhihong Wang, Zhengle Chen, Eleonora Seitmuratova, Shuqin Han, Qi Zhou, Baoying Ye (2014) Original Research Article, SHRIMP U-Pb, Ar-Ar and fission-track geochronology of W-Mo deposits in the Balkhash Metallogenic Belt (Kazakhstan), Central Asia, and the geological implications, Journal of Asian Earth Sciences, In Press, Corrected Proof, Available online 23 July 2014.

12. Baltabek Ibrayev, Lyudmila Lider, Christian Bauer (2015) Original Research Article Gasterophilus spp. infections in horses from northern and central Kazakhstan, Veterinary Parasitology, Volume 207, Issues 1-2, 15 January 2015, pp. 94-98.

13. Alexander O. Averianov, J. David Archibald, Pavel P. Skutschas, Gareth J. Dyke (2014) Original Research Article New mammal remains from the Late Cretaceous Bostobe Formation (Northeast Aral Sea Region, Kazakhstan), Palaeoworld, Volume 23, Issues 34, September-December 2014, pp. 314-320.

14. Kazbek Toleubayev, Kees Jansen, Arnold van Huis (2010) Original Research Article Commodification of science and the production of public goods: Plant protection research in Kazakhstan, Research Policy, Volume 39, Issue 3, April 2010, pp. 411-421.
15. Korobkin VV, Buslov MM (2011) Original Research Article Tectonics and geodynamics of the western Central Asian Fold Belt (Kazakhstan Paleozoides), Russian Geology and Geophysics, Volume 52, Issue 12, December 2011, pp. 1600-1618,

16. Vitaliy Salnikov, Galina Turulina, Svetlana Polyakova, Yevgeniya Petrova, Aizhan Skakova (2015) Original Research Article Climate change in Kazakhstanduring the past 70 years, Quaternary International, Volume 358, 9 February 2015, pp. 77-82,

17. Carol Dahl, Karlygash Kuralbayeva (2001) Original Research Article Energy and the environment in Kazakhstan, Energy Policy, Volume 29, Issue 6, May 2001, pp. 429440.

18. Todd E. Katzner, Evgeny A. Bragin, E.J. MilnerGulland (2006) Original Research Article Modelling populations of long-lived birds of prey for conservation: A study of imperial eagles (Aquila heliaca) inKazakhstan, Biological Conservation, Volume 132, Issue 3, October 2006, pp. 322-335.

19. Min Ran, Zhaodong Feng (2014) Original Research Article Variation in carbon isotopic composition over the past ca. 46,000 $\mathrm{yr}$ in the loess-paleosol sequence in central Kazakhstan and paleoclimatic significance, Organic Geochemistry, Volume 73, August 2014, pp. 47-55.

20. Weber B, Steiner M, Evseev S, Yergaliev G (2013) Original Research Article First report of a Meishucun-type early Cambrian (Stage 2) ichnofauna from the Malyi Karatau area (SE Kazakhstan): Palaeoichnological, palaeoecological and palaeogeographical implications, Palaeogeography, Palaeoclimatology, Palaeoecology, Volume 392, 15 December 2013, pp. 209-231.

21. Susanne Bauer, Boris Gusev, Tatyana Belikhina, Timur Moldagaliev, Kazbek Apsalikov (2013) Chapter 14 - The Legacies of Soviet Nuclear Testing in Kazakhstan: Fallout, Public Health and Societal Issues, Radioactivity in the Environment, Volume 19, 2013, pp. 241-258.

22. José Antonio Sánchez-Zapata, Martina Carrete, Andrei Gravilov, Sergei Sklyarenko, Olga Ceballos, José Antoni Donázar, Fernando Hiraldo (2003) Original Research Article Land use changes and raptor conservation in steppe habitats of Eastern Kazakhstan, Biological Conservation, Volume 111, Issue 1, May 2003, pp. 71-77.

23. Tatyana Vakhlamova, Hans-Peter Rusterholz, Yuliya Kanibolotskaya, Bruno Baur (2014) Original Research Article Changes in plant 
diversity along an urban-rural gradient in an expanding city in Kazakhstan, Western Siberia Landscape and Urban Planning, Volume 132, December 2014, pp. 111-120,

24. Angela A. Bruch, Sergey G. Zhilin (2007) Original Research Article Early miocene climate of Central Eurasia - Evidence from Aquitanian floras of Kazakhstan, Palaeogeography, Palaeoclimatology, Palaeoecology, Volume 248, Issues 1-2, 14 May 2007, pp. 32-48.

25. Dusipov ES, Batyrbaev NM, Uderbaev NN, Shalkharov YS (2015) Original Research Article
“APPLIED ASPECTS OF APPLICATION OF INSURANCE OF PROFESSIONAL RESPONSIBILITY OF DOCTOR IN MEDICAL CONFLICTS AND AFFECTING MECHANISMS ON AREA OF PROSECUTION IN KAZAKHSTAN REPUBLIC, CENTRAL ASIA:DISCRIPTIVE APPROACH", International Scientific Journal "Theoretical and Applied Science" volume 21. Issues 01 Published: 30.01.2015. pp.89-93. Soi: http://s-o-i.org/1.1/TAS*01(21)16 